\title{
LEVANTAMENTO DE PERFIS RADIOMÉTRICOS NOS SEDIMENTOS PERMIANOS DA BACIA DO PARANÁ NO LESTE DO ESTADO DE SÃO PAULO
}

\author{
Elisabeth de Fátima Strobino \\ Orientador: Dr. Fernando Brenha Ribeiro (IAG-USP) \\ 85 p. - Dissertação (Mestrado) - Defesa 19.05.2005
}

RESUMO. Um levantamento radiométrico foi realizado ao longo de dois cortes de estrada na rodovia Castelo Branco. Em um dos cortes foram encontrados sedimentos pertencentes às Formações Corumbataí da bacia do Paraná, enquanto que no outro são encontrados sedimentos pertencentes às Formações Corumbataí em contato com sedimentos da Formação Pirambóia. A diferença no nível de deposição dos sedimentos observados nos dois cortes de estrada é de, aproximadamente, $25 \mathrm{~m}$. 0 equipamento utilizado foi um espectrômetro gama portátil previamente calibrado para esse levantamento. Os levantamentos revelaram uma variação significativa na radioatividade como função do nível de deposição dos sedimentos da Formação Corumbataí. Os sedimentos depositados próximo ao contato com a Formação Pirambóia, que formam uma sucessão de siltitos intercalados com camadas de arenito fino, apresentam uma radioatividade menor do que os siltitos depositados no nível inferior. Essa diferença é devida à menor concentração de potássio e de tório nas camadas de arenito. As concentrações dos elementos radioativos e a taxa de exposição permitiram a divisão dos sedimentos da Formação Corumbataí e da Formação Pirambóia, vistos no corte de estrada do quilômetro 166, uma estrutura de camadas. A resolução dos dados radiométricos é limitada e uma comparação do modelo em camadas proposto com a litologia identificada diretamente na exposição dos sedimentos mostra que, em alguns casos, camadas de sedimentos diferentes são englobadas em uma única camada definida pela radioatividade. Apesar dessa limitação, os resultados mostram que uma estrutura em camadas, com a espessura de algumas dezenas de centímetros, pode ser revelada, ainda que com imperfeições, pela técnica da espectrometria gama de campo.

ABSTRACT. A gamma Ray survey was done in two sediments exposures in Paraná Basin. In the first exposure, sediments belonging to the Corumbataí Formation can be seen. In the second exposure, deposited in a stratigraphic level about 25 meters above, Corumbataí Formation is observed in contact with sediments belonging to the Pirambóia Formation. The gamma ray survey revealed a significant variation in the radioactivy of the Corumbataí Formation sediments as a function of the deposition level. Near the contact with the Pirambóia Formation, The Corumbataí siltstone and sandstone intercalated layers are less radioactive than the Corumbatai siltstones deposited in the lower level. The difference is due to the smaller potassium and thorium concentration in the sandstone layers. The radioactive element concentrations and the exposure rates allowed the proposition of a layered model for the Corumbataí and Pirambóia sediments seen in the second exposure. The model resolution is limited and a comparison with the lithology actually seen shows that, in some cases, different lithologies were put together in a single layer. In spite of this limitation, the results showed that a layered sediment deposit, with layers about $30 \mathrm{~cm}$ to $40 \mathrm{~cm}$ thick, can be revealed by a field gamma ray survey. 